\title{
Taxonomic Utility of Restriction Endonuclease Fingerprinting of Large DNA Fragments from Streptomyces Strains
}

\author{
MARTHA BEYAZOVA $\dagger$ AND MARY P. LECHEVALIER ${ }^{*}$ \\ Waksman Institute of Microbiology, Rutgers University, Piscataway, New Jersey, 08855-0759
}

\begin{abstract}
Using a method known as low-frequency restriction fragment analysis (LFRFA) (M. L. Beyazova and M. P. Lechevalier, Int. J. Syst. Bacteriol. 42:422-433, 1992), we determined the molecular weights of AseI restriction fragments of Streptomyces DNAs by pulsed-field gel electrophoresis. The levels of similarity of fragment patterns among strains were determined by using the simple matching coefficient, and clustering was performed by using the unweighted pair group with mathematical average algorithm. A total of 59 strains representing eight species and the numerically classified taxon Streptomyces cyaneus group A18 (S. T. Williams, M. Goodfellow, G. Alderson, E. M. H. Wellington, P. H. A. Sneath, and M. J. Sackin, J. Gen. Microbiol. 129:1743-1813, 1983) were studied. Forty-two strains (six species) formed eight clusters at levels of similarity of more than $80 \%$; 17 strains (including the entire $S$. cyaneus group) were unclustered. Cluster 1 contained all of the Streptomyces albus strains studied plus two strains of Streptomyces somaliensis and two strains of Streptomyces lavendulae. Cluster 2 contained 8 of the 12 Streptomyces fradiae strains examined plus one strain each of $S$. somaliensis and $S$. lavendulae. Cluster 3 was heterogeneous in terms of species. Cluster 4 contained two $S$. somaliensis strains; cluster 5 contained three $S$. fradiae strains; cluster 6 contained three Streptomyces rimosus strains; and clusters 7 and 8 contained seven and three Streptomyces ipomoea strains, respectively. The S. cyaneus group strains exhibited no clustering among themselves or with the other species examined. Some Streptomyces species which exhibited high levels of similarity (85 to $95 \%$ ) in physiological tests (e.g., S. albus and the $S$. fradiae strains in cluster 2) exhibited high levels of similarity in the LFRFA (84 and 81\%, respectively). Other taxa ( $S$. cyaneus group) which exhibited equally high levels of physiological similarity $(90 \%)$ appeared to be unrelated as determined by the LFRFA. Species with lower levels of physiological similarity (e.g., $S$. somaliensis [75\%], $S$. lavendulae $[63 \%]$, and $S$. rimosus $[68 \%]$ ]) exhibited low levels of LFRFA similarity $(75,64$, and 54\%, respectively). High levels of DNA-DNA relatedness $(>90 \%)(S$. ipomoea) were reffected in high levels of similarity as determined by the LFRFA (75 to $100 \%)$; lower levels of DNA-DNA relatedness (ca. $70 \%)(S$. cyaneus group) were reflected in low levels of LFRFA similarity (strains not clustered). We concluded that the presently used physiological tests reflect too small a portion of the genome to be universally useful in streptomycete species characterization. In contrast, high levels of DNA-DNA relatedness $(>90 \%)$ and high LFRFA similarity values will probably both be valuable in species delineation in actinomycetes.
\end{abstract}

Restriction enzymes which generate many DNA fragments yield patterns which are strain specific but are not useful in delineating species (7). When enzymes with low-frequency cleavage are used (28), the DNA fragments generated are fewer and larger, but must be separated by using special electrophoretic techniques, such as the pulsed-field technique. The molecular weights of such fragments can readily be determined by comparison with suitable standards, and the frequency and stability of specific restriction sites in genomic DNA can be determined. Since in the actinomycete genus Streptomyces the G+C content of the DNA is very high (69 to $78 \mathrm{~mol} \%$ ), it seemed likely that the AT-rich regions are conserved areas of importance in the genome. Using enzymes recognizing only AT-rich sites, we performed a low-frequency restriction fragment analysis (LFRFA) of a number of Streptomyces strains and in this paper describe the results obtained for 15 species of this genus.

\section{MATERIALS AND METHODS}

Bacterial strains. The strains included in this study are shown in Table 1.

\footnotetext{
* Corresponding author.

$\dagger$ Present address: Schering-Plough Research Institute, Kenilworth, NJ 07033-0539.

¥ Present address: RR 2, Box 2235, Morrisville, VT 05661.
}

Media and growth conditions. All strains were maintained on Bennett agar slants (37) and grown in Trypticase soy broth (BBL) under static conditions at $28^{\circ} \mathrm{C}$ for 3 to 4 days.

Physiological tests. The physiological tests of Gordon (9, 10 ), Gordon and Horan (11), and Mishra et al. (30) were used.

Preparation of cells and inserts. For analysis, cells were collected, washed with 0.5 M EDTA (all of the EDTA used was at $\mathrm{pH} 8$ ), ground, extracted with water-saturated phenol (27) for $20 \mathrm{~min}$ at $65^{\circ} \mathrm{C}$, and then washed three times with $\mathrm{CHCl}_{3}$-isoamyl alcohol $(24: 1)$ at room temperature. The resulting samples were treated with $2 \%$ sodium dodecyl sulfate (SDS) $-5 \mathrm{mM}$ EDTA at $65^{\circ} \mathrm{C}$ for $30 \mathrm{~min}$, washed three times with $5 \mathrm{mM}$ EDTA containing $1 \mathrm{mg}$ of bovine serum albumin fraction $\mathrm{V}$ (Sigma Chemical Co.) per $\mathrm{ml}$, and then washed three times with $10 \mathrm{mM}$ EDTA. Finally, the cells were suspended in TE ( $10 \mathrm{mM}$ Tris-1 mM EDTA) and mixed with low-melting-point temperature agarose (final agarose concentration, $0.5 \%$ ), and these inserts were incubated for 3 to $4 \mathrm{~h}$ or overnight (the time was not critical) at $37^{\circ} \mathrm{C}$ in $\mathrm{EC}$ lysis buffer (35) containing $1 \mathrm{mg}$ of lysozyme per ml. Next, the samples were digested at $37^{\circ} \mathrm{C}$ with $1 \mathrm{mg}$ of subtilisin Carlsberg (Sigma Chemical Co.) per $\mathrm{ml}$ for 3 to $4 \mathrm{~h}$ or overnight with gentle shaking and washed with $\mathrm{TE}$ at $56^{\circ} \mathrm{C}$.

Restriction of DNA. Restriction enzymes DraI, AseI (or its isoschizomer AsnI), and SpeI were purchased from Bethesda Research Laboratories, New England Biolabs, or Boeringer-Mannheim. Restriction digestions were per- 
TABLE 1. Streptomyces strains investigated in this study

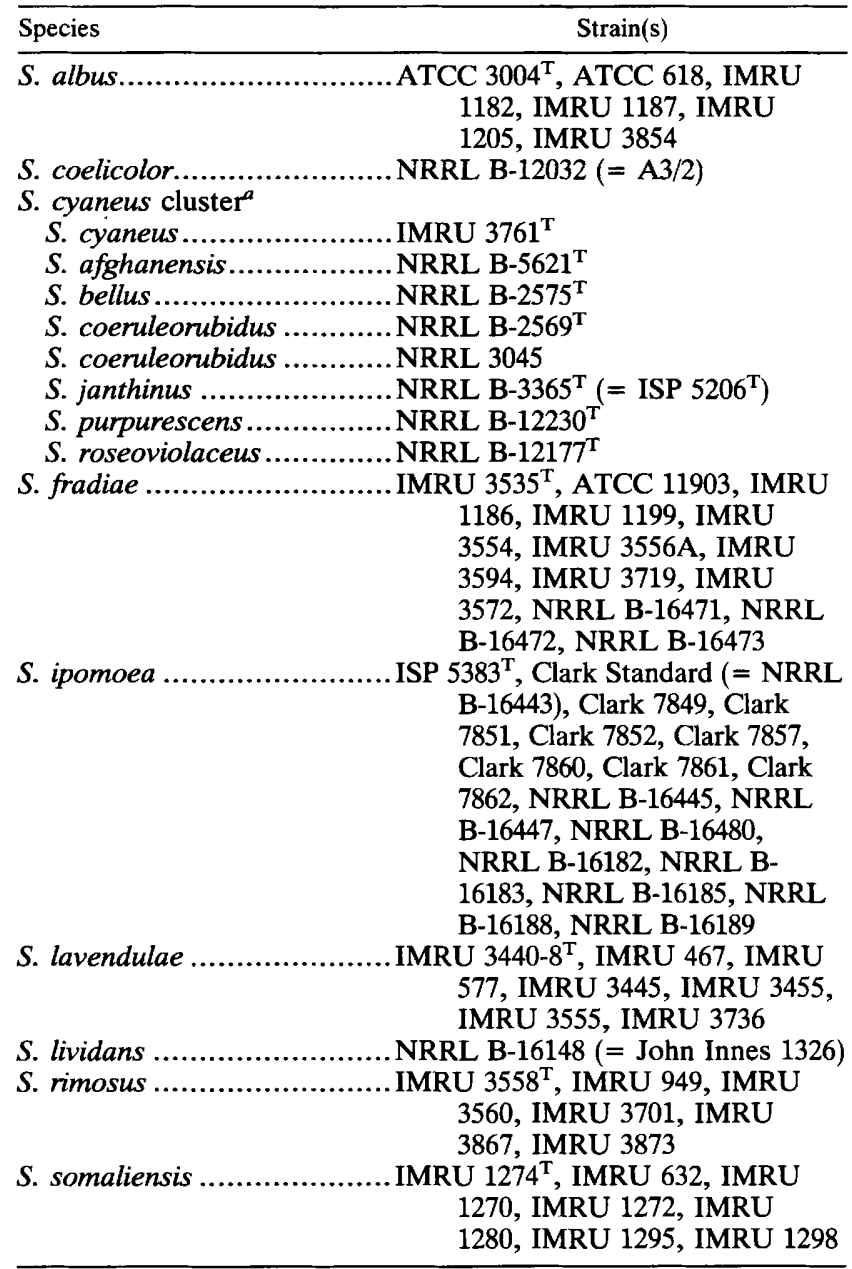

${ }^{a}$ Cluster A18 of Williams et al. (39).

formed by using the method of Smith and Cantor (35) and the manufacturers' recommendations.

PFGE. Pulsed-field gel electrophoresis (PFGE) was performed on $0.8 \%$ agarose gels in $1 \times$ Tris-borate buffer ( $\mathrm{pH} 8$ ) in a Beckman Geneline TAFE apparatus. In most cases the following programs were used: (i) for fragments having molecular sizes of 200 to $1,500 \mathrm{~kb}$, a first stage consisting of $12 \mathrm{~h}$ at $150 \mathrm{~V}$ with a 70-s pulse time and a second stage consisting of $14 \mathrm{~h}$ at $150 \mathrm{~V}$ with a 2-min pulse time (the standard used was Saccharomyces cerevisiae chromosomes); and (ii) for fragments having molecular sizes of 50 to $500 \mathrm{~kb}$, one stage consisting of $20 \mathrm{~h}$ at $140 \mathrm{~mA}$ with a $25-\mathrm{s}$ pulse time in $1 \%$ Tris-acetate buffer (the standard used was $\lambda$ concatemers). The gels were stained with ethidium bromide, visualized at $302 \mathrm{~nm}$, and photographed with Polaroid type 55 or 57 film.

Plasmid detection. For plasmid detection samples were prepared as described above until the restriction step. Strains displaying bands in the $100-$ to $1,500-\mathrm{kb}$ range were subjected to PFGE with the second program (see above) to distinguish between giant linear plasmids (GLPs) and supercoiled (SC) plasmids (14).

Numerical analysis. Similarity levels were calculated by using the Taxan program (version 2.0) of David Swartz, Biotechnology Institute, University of Maryland, and the simple matching coefficient, and cluster analysis was performed by the unweighted average pair group method (36). Clusters were distinguished at levels of similarity of $80 \%$ or greater. Data were coded as 0 (negative) or 1 (positive).

\section{RESULTS}

Using LFRFA, we analyzed 59 Streptomyces strains belonging to 15 species. We grouped together seven of these species (Table 1) as representatives of the Streptomyces cyaneus cluster proposed by Williams et al. (39) on the basis of numerical taxonomic data. The Streptomyces albus, Streptomyces lavendulae, Streptomyces rimosus, and Streptomyces somaliensis strains were identified by Gordon (10), Gordon and Horan (11), and Mishra et al. (30) on the basis of phenotypic test results. Of the 12 Streptomyces fradiae strains examined by the LFRFA in this study, 9 were identified by Gordon (10) and Mishra et al. (30) on the basis of physiological characteristics, and 3 (NRRL B-16471, NRRL B-16472, and NRRL B-16473), a tylosin producer and two mutants, were tentatively assigned to $S$. fradiae by McGuire et al. (29). The Streptomyces ipomoea strains were all isolated from sweet potato rot; they included the type strain, ISP 5383, nine strains isolated by C. A. Clark or W. J. Martin in the United States (6), and two strains isolated by T. Suzui in Japan (23). The DNA fragments generated in this analysis ranged from 100 to $1,500 \mathrm{~kb}$ long. In all cases the fragments were well resolved by PFGE, and differences among strains could clearly be detected.

Pretreatment. In preliminary experiments it was found that the original procedure for preparing bacterial inserts for pulsed-field analysis described by Smith and Cantor (35) and used by us with modifications for strains belonging to the actinomycete genus Frankia (3) yields unrestricted, incompletely restricted, or degraded streptomycete DNA. The growth conditions used, pretreatment of cells, and extraction with water-saturated phenol (see Materials and Methods) provided the clear, interpretable, highly reproducible results desired with all of the Streptomyces strains examined thus far.

Plasmids. An examination of unrestricted DNAs from the strains used in this study subjected to PFGE analysis showed that GLPs or SC plasmids were often present (Table 2 ). Many strains of $S$. ipomoea and all of the $S$. lavendulae strains tested contained at least one GLP (Fig. 1). The largest linear plasmid (length, $>1,000 \mathrm{~kb}$ ) was found in $S$. lavendulae strain IMRU 467.

Restriction enzyme-specific patterns. We evaluated the potential usefulness of different restriction enzymes for generating low-frequency restriction fragments having lengths suitable for analysis. All of the patterns generated by SpeI (A'CTAG) were complex, containing numerous fragments (e.g., Fig. 2, S. albus). The DraI restrictase (TTT'AAA) produced either simple patterns with three to five DNA fragments (Fig. 3, S. albus) or patterns with numerous fragments (Fig. 4, S. ipomoea). Some $S$. somaliensis strains seemed to have no detectable DraI sites at all (data not shown). Restriction with AseI (AT'TAAT) gave rise to between 3 to 15 fragments in the strains studied (Fig. 5 and 6 and Table 3). As most of the AseI-generated fragments were sufficiently numerous to provide meaningful discrimination among strains and they fell within the molecular size range amenable to good separation with PFGE, we used this enzyme for the analyses described below.

Strain- and/or species-specific patterns. There were no LFRFA patterns found that were specific for all strains of a 
TABLE 2. Linear plasmid contents of the Streptomyces strains used in this study

\begin{tabular}{lll}
\hline \multicolumn{1}{c}{ Taxon } & \multicolumn{1}{c}{ Strain } & \multicolumn{1}{c}{ Plasmid size(s) (kb) } \\
\hline S. fradiae & IMRU 3556A & 184,250 \\
& NRRL B-16471 & 440 \\
& NRRL B-16472 & 440 \\
& & \\
S. rimosus & IMRU 3558 & 260 \\
& IMRU 3701 & 260 \\
& IMRU 949 & $<100$ \\
S. cyaneus cluster & NRRL B-12177 & 180 \\
& NRRL B-12230 & 90 \\
S. lavendulae & & \\
& IMRU 467 & $370,1,000$ \\
& IMRU 577 & 100 (SC plasmid?) \\
& IMRU 3440-8 & 275 (SC plasmid?) \\
& IMRU 3455 & 90,275 \\
& IMRU 3555 & 370,400 \\
& IMRU 3736 & 700 \\
& & \\
S. ipomoea & NRRL B-16483 & 270 \\
& NRRL B-16485 & $<90$ \\
& NRRL B-16488 & $<90,270$ \\
& NRRL B-16489 & $<90,270$ \\
& NRRL B-16447 & $<90$ \\
\hline
\end{tabular}

given species. In most cases the patterns were strain specific. However, there were cases of identical or highly related patterns (similarity levels, $>94 \%$ ) found within groups of strains identified as $S$. albus, $S$. fradiae, $S$. ipomoea, $S$. lavendulae, $S$. rimosus, or $S$. somaliensis. None of the members of the $S$. cyaneus cluster examined exhibited a close relationship to other members of the cluster or to the strains of the other species examined.

Numerical analysis. For purposes of numerical analysis,

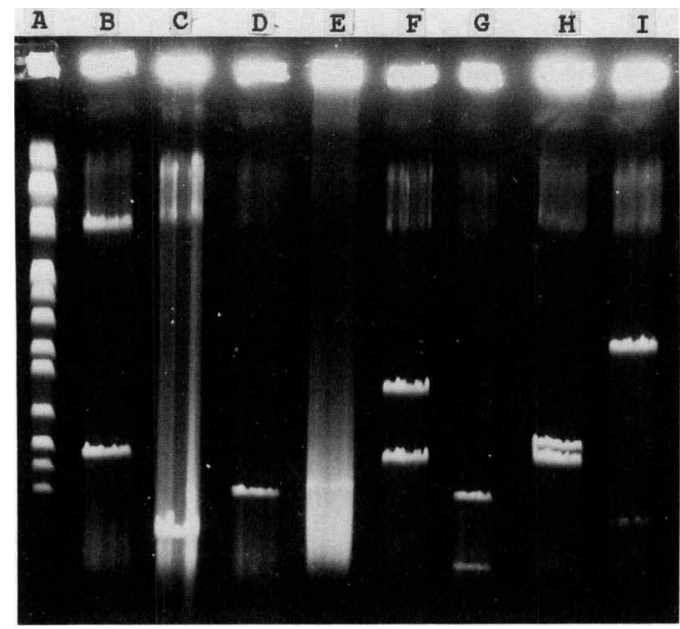

FIG. 1. Pulsed-field gel of $S$. lavendulae strains (unrestricted), showing positions of plasmids. Lane A, Saccharomyces cerevisiae chromosomal standard (chromosome sizes from bottom to top, 260, $290,370,460,580,650,763,835,864,991,1,047,1,285$, and 1,500 kb); lane B, IMRU 467 (GLP); lane C, IMRU 577 (GLP); lane D, IMRU 3440-8 ${ }^{\mathrm{T}}$ (GLP); lane E, IMRU 3440-14 (GLP); lane F, IMRU 3445 (GLP); lane G, IMRU 3455 (upper band, GLP; lower band, SC plasmid); lane H, IMRU 3555 (GLP); lane I, IMRU 3736 (upper band, GLP; lower band, SC plasmid?).

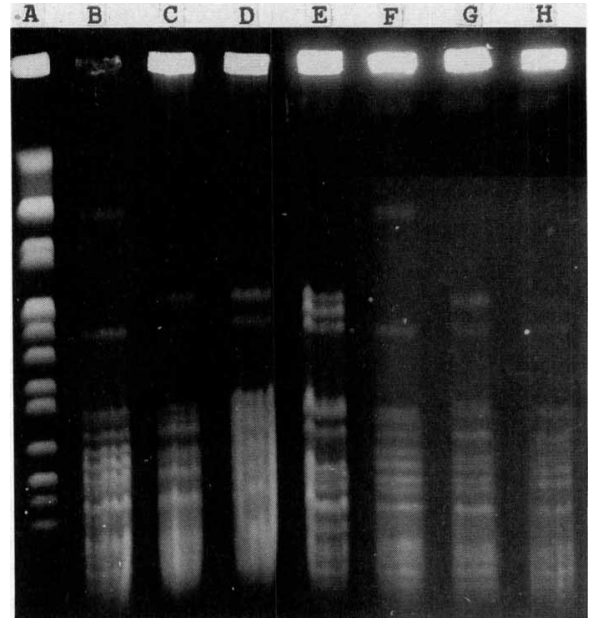

FIG. 2. Pulsed-field gel of $S$. albus strains restricted with SpeI. Lane A, Saccharomyces cerevisiae chromosomal standard (see the legend to Fig. 1); lane B, ATCC $3004^{\mathrm{T}}$; lane C, IMRU 1182; lane D, IMRU 3854; lane E, IMRU 1205; lane F, ATCC 618; lane G, IMRU 1187; lane H, IMRU 3854.

because of (i) the inevitable error inherent in estimating the sizes of large fragments (35) and (ii) the possibility of deleted or amplified sequences, which are common in Streptomyces strains (4), we grouped together bands in 30-kb ranges except for bands larger than $1,080 \mathrm{~kb}$, a highly compressed area for which $140-\mathrm{kb}$ intervals were used (Table 3 ). Figure 7 shows a dendrogram giving the levels of relatedness for the various strains based on the numerical analysis of the data. Of the 59 strains tested, $42(71 \%)$ were distributed among eight clusters related at similarity levels of $80 \%$ or greater; 17 $(29 \%)$ of the strains were not clustered (Table 3 ).

All strains designated $S$. albus were restricted by both DraI and AseI in a manner similar to the restriction of type culture ATCC 3004, giving rise to three and four or five fragments, respectively (Fig. 5) (DraI data not shown). Most

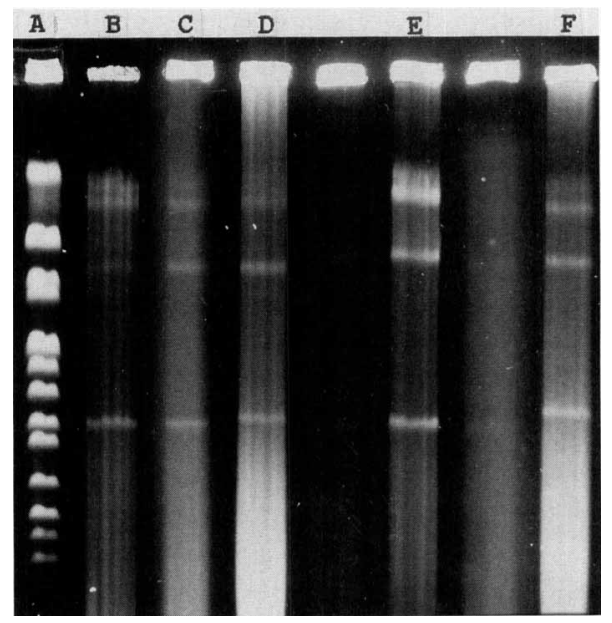

FIG. 3. Pulsed-field gel of $S$. albus strains restricted with DraI. Lane A, Saccharomyces cerevisiae chromosomal standard (see the legend to Fig. 1); lane B, ATCC $3004^{\mathrm{T}}$; lane C, ATCC 618; lane D, IMRU 1182; lane E, IMRU 1205; lane F, IMRU 3854. 


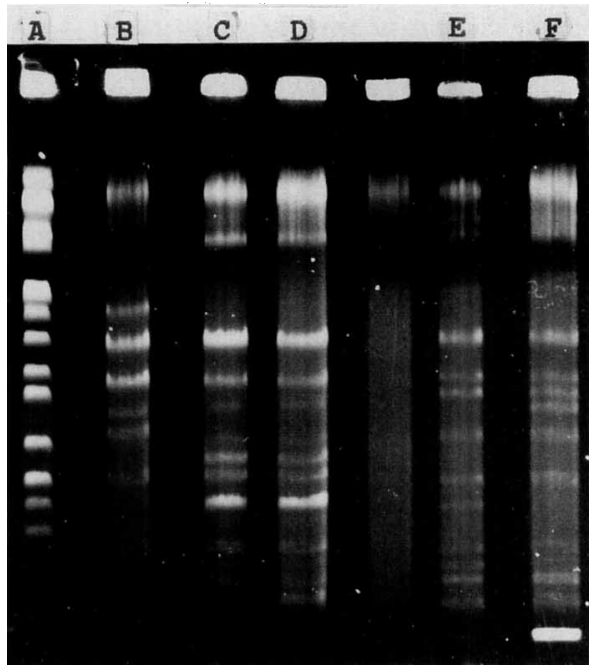

FIG. 4. Pulsed-field gel of $S$. ipomoea strains restricted with DraI. Lane A, Saccharomyces cerevisiae chromosomal standard (see the legend to Fig. 1); lane B, NRRL B-16480; lane C, NRRL B-16483; lane D, NRRL B-16489; lane E, NRRL B-16445; lane F, NRRL B-16447.

of the strains also exhibited strain-specific digestion differences; the only exception was $S$. albus ATCC 618, which seemed to be identical to the type strain. All of the $S$. albus strains were found together in cluster 1 (Fig. 7 and Table 3).

Among the $S$. somaliensis strains, only one, IMRU 1280 , was restricted by AseI in a manner which gave a pattern very similar to that of the type strain, ATCC 1274. These two strains were grouped in cluster 1 . The rest of the $S$. somaliensis strains showed more complicated digestion patterns and were scattered among clusters 2 through 4 or were not clustered. Between five and eight fragments were generated in all strains of $S$. somaliensis with Ase I; in contrast, these strains exhibited relative or complete insensitivity to DraI,

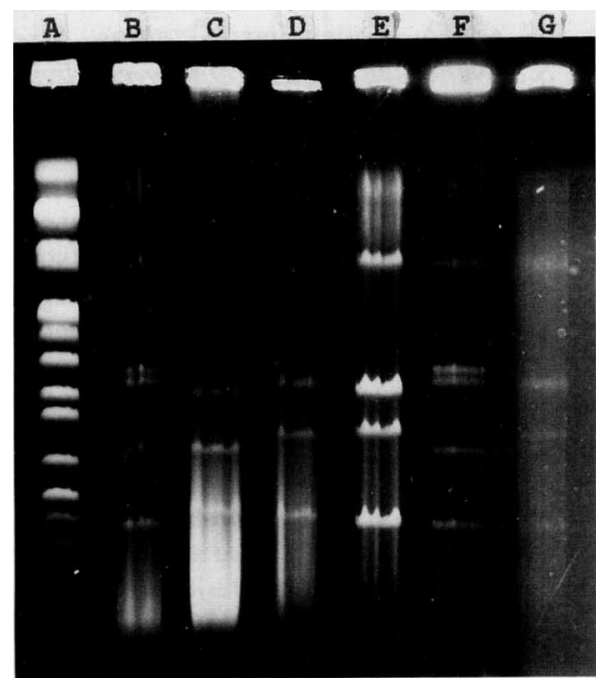

FIG. 5. Pulsed-field gel of $S$. albus strains restricted with AseI. Lane A, Saccharomyces cerevisiae chromosomal standard (see the legend to Fig. 1); lane B, ATCC $3004^{\mathrm{T}}$; lane C, IMRU 1182; lane D, IMRU 3854; lane E, IMRU 1205; lane F, ATCC 618; lane G, IMRU 1187.

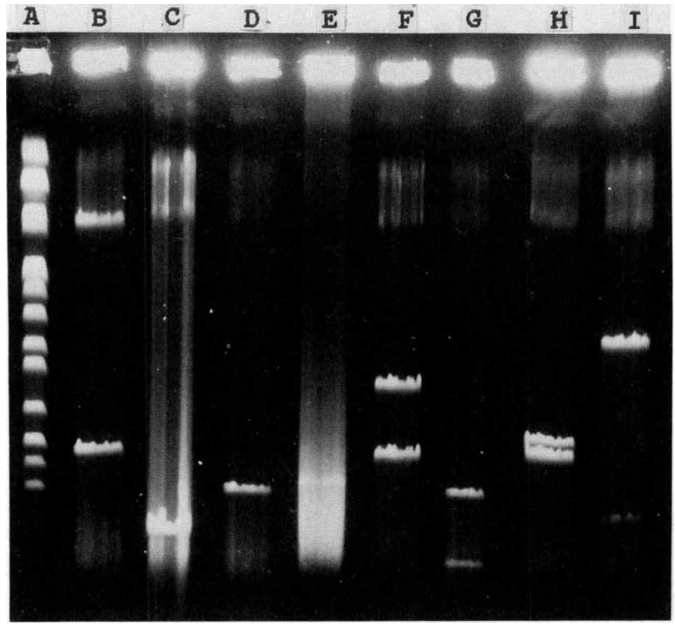

FIG. 6. Pulsed-field gel of $S$. ipomoea strains restricted with AseI. Lane A, Saccharomyces cerevisiae chromosomal standard (see the legend to Fig. 1); lane B, ISP $5383^{\mathrm{T}}$; lane C, Clark Standard (= NRRL B-16443); lane D, Clark 7849; lane E, Clark 7851; lane F, Clark 7852; lane G, Clark 7857; lane H, Clark 7860; lane I, Clark 7861.

with zero to three restriction fragments produced (data not shown).

When AseI was used, two clusters (clusters 2 and 5) were observed with the $S$. fradiae strains (Fig. 7). The cluster 2 strains yielded three to six DNA fragments with this enzyme, whereas the cluster 5 strains yielded eight or nine fragments. The same two groups were distinguished by DraI (data not shown). Differences were detected in the tylosin producer and its two mutants (NRRL B-16471, NRRL B-16472, and NRRL B-16473), but these strains clustered at a similarity level $93 \%$.

All of the $S$. ipomoea strains except the type strain could be recognized by their similar Ase I digestion profiles (Fig. 6). They formed two closely related clusters (clusters 7 and 8) linked to each other at a similarity level of $76 \%$. The cluster 7 strains yielded 10 to 13 DNA fragments, and the cluster 8 strains yielded 12 to 15 fragments, with many fragments in the low-molecular-size range $(<200 \mathrm{~kb})$. The type strain, ISP 5383 , did not cluster with any of the other $S$. ipomoea strains studied.

AseI digestions of $S$. lavendulae strains without preliminary plasmid elimination produced 9 to 12 fragments (data not shown). Plasmid-free samples yielded simpler strainspecific patterns (data not shown) having 3 to 10 fragments, and these patterns were used in the numerical analysis. Two strains, including the type strain, were found in cluster 1 and were related to each other at a similarity level of $97 \%$. The other strains were found in clusters 2 and 3 or were unclustered.

All of the strains designated $S$. rimosus yielded 11 to 13 bands after AseI digestion. Three of the $S$. rimosus strains (IMRU 3558 ${ }^{\mathrm{T}}$, IMRU 3701, and IMRU 3873) were identical as determined with both AseI and DraI (data not shown) and formed a cluster by themselves (cluster 6) (Fig. 7). The other two strains studied were unclustered; they were related to each other at a similarity level of only $73 \%$ and were remote from the other $S$. rimosus strains in cluster 6.

An analysis of the AseI digests of the $S$. cyaneus cluster strains showed that these strains were not related to each other or to the other strains studied; none of them were 
TABLE 3. Distribution of AseI fragments of various sizes within the clusters of Streptomyces strains

\begin{tabular}{|c|c|c|c|c|c|c|c|c|c|c|c|c|c|c|c|c|c|c|c|}
\hline \multirow{2}{*}{ Cluster } & \multirow{2}{*}{$\begin{array}{l}\text { No. of } \\
\text { strains }\end{array}$} & \multicolumn{2}{|c|}{$\begin{array}{c}\text { No. of } \\
\text { fragments }\end{array}$} & \multirow{2}{*}{$\begin{array}{l}\text { Cluster composition } \\
\text { (no. of strains } \\
\text { of each species) }\end{array}$} & \multicolumn{15}{|c|}{$\%$ of strains having AseI fragments in the following size ranges $(\mathrm{kb})^{a}$ : } \\
\hline & & Avg & Range & & $\begin{array}{l}90- \\
119\end{array}$ & $\begin{array}{l}150- \\
179\end{array}$ & $\begin{array}{c}180- \\
209\end{array}$ & $\begin{array}{l}210- \\
239\end{array}$ & $\begin{array}{c}240- \\
269\end{array}$ & $\begin{array}{l}270- \\
299\end{array}$ & $\begin{array}{c}300- \\
329\end{array}$ & $\begin{array}{c}330- \\
359\end{array}$ & $\begin{array}{c}360- \\
389\end{array}$ & $\begin{array}{c}390- \\
419\end{array}$ & $\begin{array}{c}420- \\
449\end{array}$ & $\begin{array}{l}450- \\
479\end{array}$ & $\begin{array}{c}480- \\
509\end{array}$ & $\begin{array}{c}510- \\
539\end{array}$ & $\begin{array}{c}540- \\
569\end{array}$ \\
\hline 1 & 10 & 4.3 & $3-5$ & $\begin{array}{l}6 S . \text { albus, } \\
2 . S . \text { somaliensis, } \\
2 S . \text { lavendulae }\end{array}$ & 0 & 0 & 0 & 20 & 0 & 60 & 10 & 30 & 0 & 0 & 0 & 10 & 50 & 30 & 20 \\
\hline 2 & 10 & 4.9 & $3-7$ & $\begin{array}{l}8 S . \text { fradiae, } \\
1 S . \text { lavendulae, } \\
1 S . \text { somaliensis }\end{array}$ & 0 & 10 & 80 & 0 & 100 & 0 & 0 & 0 & 10 & 0 & 10 & 10 & 10 & 0 & 10 \\
\hline 3 & 3 & 4.7 & $4-6$ & $\begin{array}{l}1 S . \text { fradiae, } \\
\quad 1 \text { S. somaliensis, } \\
1 \text { S. lavendulae }\end{array}$ & 0 & 100 & 33 & 33 & 0 & 0 & 0 & 0 & 0 & 66 & 0 & 0 & 0 & 0 & 0 \\
\hline 4 & 2 & 7.5 & $7-8$ & $2 S$. somaliensis & 0 & 100 & 0 & 100 & 50 & 50 & 0 & 0 & 50 & 0 & 0 & 0 & 0 & 0 & 0 \\
\hline 5 & 3 & 8.3 & $8-9$ & $3 S$. fradiae & 100 & 100 & 0 & 0 & 0 & 100 & 0 & 0 & 0 & 66 & 0 & 0 & 0 & 100 & 0 \\
\hline 6 & 3 & 13 & 13 & $3 S$. rimosus & 100 & 0 & 100 & 0 & 0 & 100 & 0 & 0 & 0 & 100 & 100 & 0 & 100 & 0 & 100 \\
\hline 7 & 8 & 12 & $11-13$ & 8 S. ipomoea & 86 & 0 & 57 & 100 & 100 & 100 & 0 & 86 & 0 & 0 & 100 & 28 & 72 & 72 & 0 \\
\hline 8 & 3 & 13 & $12-15$ & $3 S$. ipomoea & 66 & 33 & 66 & 100 & 100 & 0 & 0 & 100 & 33 & 33 & 100 & 100 & 66 & 66 & 66 \\
\hline
\end{tabular}

${ }^{a}$ Data for the 120- to $149-\mathrm{kb}, 570-$ to $599-\mathrm{kb}$, and 1,020- to 1,049-kb ranges have been omitted because no AseI fragments with these sizes were observed for any strain.

found in any of the clusters. These strains yielded between 9 and 12 fragments.

\section{DISCUSSION}

The genus Streptomyces is the largest genus in terms of number of species among the actinomycetes, and its members are also the predominant actinomycetic forms in nature. Included in the genus are producers of antibiotics (e.g., $S$. fradiae, $S$. rimosus, $S$. lavendulae), as well as pathogens of sweet potato (S. ipomoea) and possibly of humans $(S$. somaliensis and $S$. albus). The taxonomy of the genus has been clarified by the finding that its members contain the $L$ isomer of diaminopimelic acid in their peptidoglycans, a characteristic shared by only about $5 \%$ of the other actinomycete genera recognized (25). However, the genus contains more than 400 validly described species, the descriptions of which are often based on very few characters. The various attempts to deal with species definitions include the International Streptomyces Project (33), the work of Mishra et al. (30), and the work of Pridham and Tresner (32). All of these workers utilized morphological and physiological characteristics. The same types of criteria were used by numerical taxonomists who proposed clustering strains on the basis of their overall similarities by using various algorithms $(38,39)$. All of these researchers have contributed to our understanding of the complexity of the genus, but none has resolved the problem of species identification in a wholly satisfactory way. Because of this workers in the field have turned to other methods, including analysis of DNA relatedness, as a route to a better definition of species (23).

We have found another technique for grouping Streptomyces strains which appears to be complementary to both the phenotypic and DNA relatedness approaches, at least in some species. It is our feeling that LFRFA of the entire streptomycete genome may be a good approach to the study of the species problem. Since sequencing and DNA relatedness determinations are long and laborious procedures, LFRFA may be an alternative solution which is rapid, accurate, and reproducible and can take into account the plasmid content of a strain. In one previous study of streptomycetes in which this technique was used (24) four strains of Streptomyces ambofaciens were examined. It was found that three strains clustered reasonably closely and one was different. Using LFRFA, we have already obtained promising results in defining species groups in the actinomycete genus Frankia (3). The method has been exploited with success in other bacteria, including brucellae (1), Escherichia coli $(2,5)$, mycobacteria (34), and pseudomonads (12).

The strains which we examined (Table 1) included the type strains of 15 species, including the type species of the genus Streptomyces, $S$. albus. Seven of these species have been grouped by phenetic methods in the so-called $S$. cyaneus cluster (cluster group A18 [39]), and their levels of DNA homology have been determined $(20,21)$. In the cases of $S$. albus, $S$. fradiae, $S$. lavendulae, $S$. rimosus, and $S$. somaliensis, we selected six to eight representative strains identified on the basis of physiological tests by Gordon. The strains and their origins have been described previously (10, $11,30)$. Some of the species which we studied have recently been investigated by other workers using different methods, including 16S rRNA sequencing ( $S$. albus, Streptomyces coelicolor, S. lavendulae, and Streptomyces lividans [40]), ribosomal protein patterns ( $S$. albus, $S$. coelicolor, and $S$. lavendulae [8, 31]), and an enzyme-linked immunosorbent assay ( $S$. rimosus [18]), although in most cases the strains tested differed from the strains which we used and it is difficult to compare the results of the various studies.

Restriction of streptomycete DNA in situ in agarose plugs for analysis by PFGE cannot be accomplished with the procedures currently in general use (35) or the modification developed by us for use with the genus Frankia (3). A simple but indispensible step in the pretreatment protocol for Streptomyces strains is water-saturated phenol extraction of the ground cells (see Materials and Methods), which results in a dramatic improvement in the restriction patterns. At the same time, the risk of DNA degradation which we and other workers $(16,41)$ have observed in many strains is eliminated or at least much reduced. Although we have not tried to elucidate the mechanism of phenol action, it can be speculated that this action is probably associated with complete denaturation of proteins inaccessible to the other reagents used in the procedure to eliminate protein interference (e.g., SDS, proteases, etc.). 
TABLE 3-Continued

\begin{tabular}{|c|c|c|c|c|c|c|c|c|c|c|c|c|c|c|c|c|c|c|}
\hline \multicolumn{19}{|c|}{$\%$ of strains having AseI fragments in the following size ranges $(\mathbf{k b})^{a}$ : } \\
\hline $\begin{array}{c}600- \\
629\end{array}$ & $\begin{array}{c}630- \\
659\end{array}$ & $\begin{array}{c}660- \\
689\end{array}$ & $\begin{array}{c}690- \\
719\end{array}$ & $\begin{array}{c}720- \\
749\end{array}$ & $\begin{array}{c}750- \\
779\end{array}$ & $\begin{array}{c}780- \\
809\end{array}$ & $\begin{array}{l}810- \\
839\end{array}$ & $\begin{array}{l}840- \\
869\end{array}$ & $\begin{array}{c}870- \\
899\end{array}$ & $\begin{array}{c}900- \\
929\end{array}$ & $\begin{array}{c}930- \\
959\end{array}$ & $\begin{array}{c}960- \\
989\end{array}$ & $\begin{array}{c}990 \\
1,019\end{array}$ & $\begin{array}{c}1,050- \\
1,079\end{array}$ & $\begin{array}{c}1,080- \\
1,219\end{array}$ & $\begin{array}{c}1,220- \\
1,359\end{array}$ & $\begin{array}{c}1,360 \\
1,499\end{array}$ & $>1,500$ \\
\hline 0 & 0 & 10 & 40 & 20 & 0 & 0 & 0 & 0 & 0 & 0 & 0 & 20 & 70 & 0 & 0 & 10 & 20 & 0 \\
\hline 0 & 0 & 0 & 10 & 0 & 10 & 0 & 0 & 0 & 0 & 0 & 10 & 0 & 10 & 20 & 50 & 40 & 80 & 10 \\
\hline 33 & 0 & 0 & 0 & 0 & 0 & 0 & 0 & 33 & 0 & 33 & 0 & 0 & 33 & 0 & 33 & 33 & 0 & 0 \\
\hline 0 & 50 & 0 & 0 & 0 & 0 & 0 & 100 & 0 & 0 & 0 & 0 & 50 & 0 & 0 & 50 & 100 & 0 & 0 \\
\hline 0 & 0 & 33 & 0 & 0 & 0 & 0 & 33 & 0 & 0 & 100 & 0 & 0 & 0 & 0 & 0 & 100 & 100 & 0 \\
\hline 100 & 0 & 0 & 100 & 0 & 0 & 100 & 0 & 0 & 100 & 100 & 0 & 0 & 0 & 0 & 0 & 100 & 0 & 0 \\
\hline 14 & 0 & 0 & 72 & 28 & 0 & 100 & 0 & 0 & 0 & 0 & 0 & 0 & 0 & 0 & 0 & 72 & 100 & 0 \\
\hline 0 & 0 & 0 & 0 & 0 & 0 & 100 & 0 & 100 & 0 & 0 & 100 & 0 & 0 & 0 & 0 & 0 & 100 & 0 \\
\hline
\end{tabular}

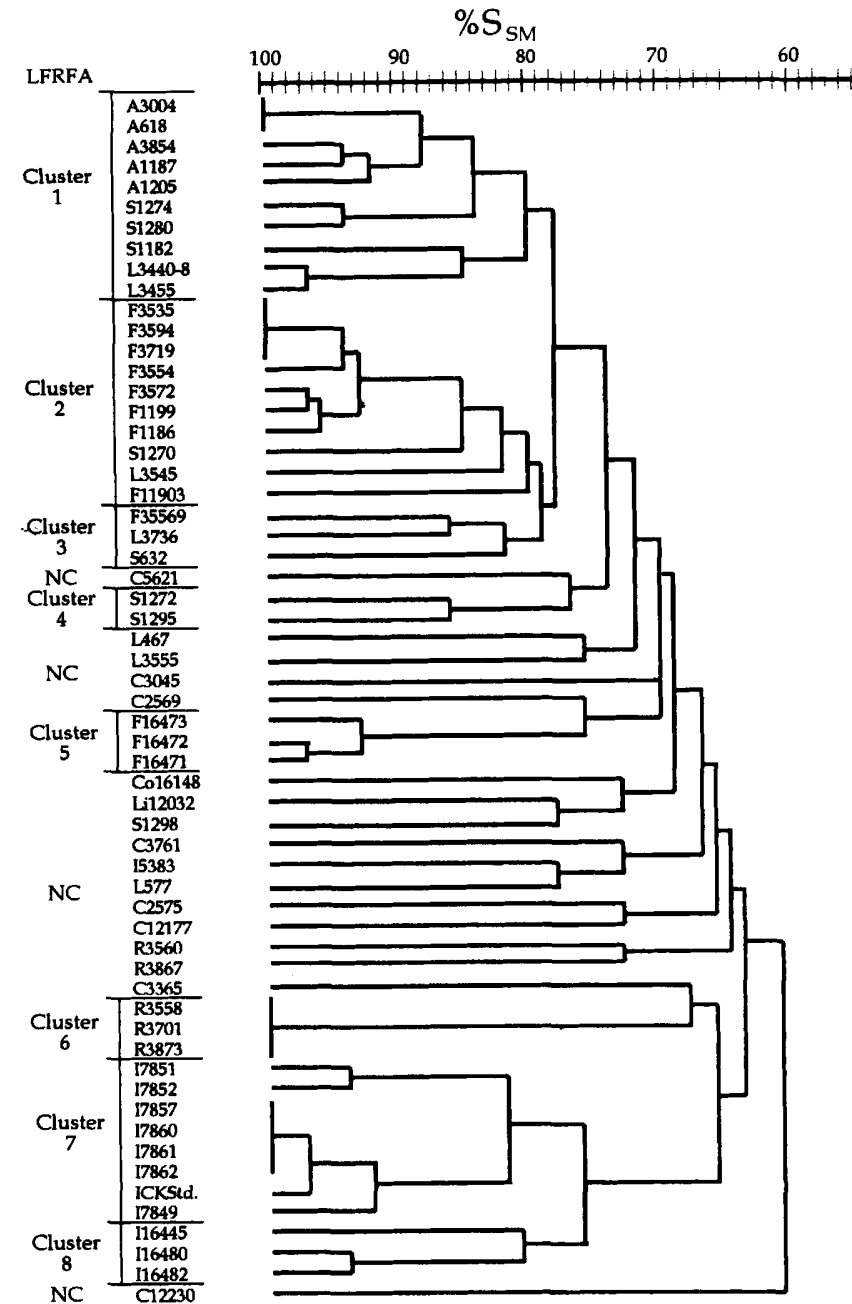

FIG. 7. Dendrogram constructed by unweighted average linkage cluster analysis of simple matching coefficient $\left(S_{\mathrm{SM}}\right)$ values for DNA fragment sizes expressed as percentages. Each of the Streptomyces strains was restricted with AseI, and the sizes of the resulting DNA fragments were calculated (see Materials and Methods). The prefixes of the strain designations indicate the species or taxon names, as follows: A, S. albus; C, S. cyaneus cluster; $\mathrm{Co}, S$. coelicolor; F, $S$. fradiae; I, S. ipomoea; L, S. lavendulae; Li, S. lividans; R, S. rimosus; S, S. somaliensis. NC, not clustered.
Proper evaluation of the taxonomic implications of the method requires also taking into account the influence of certain factors. The first factor to be considered is the plasmid content of the strains. The existence of GLPs and/or SC plasmids could jeopardize the reliability of the patterns. As shown in Table 2, many of the streptomycete strains which we investigated contain GLPs. Finding such plasmids is not a new development. The detection of GLPs has been reported in Nocardia opaca (15) and at least eight antibioticproducing Streptomyces spp. $(13,17)$, including two tylosinproducing $S$. fradiae strains used in our study. The value which we determined for GLP size in one of the strains which we used $(440 \mathrm{~kb})$ is in agreement with previously published data (ca. $400 \mathrm{~kb}$ [13]). We confirmed the finding that plasmids are also present in many $S$. ipomoea strains (19). Our data extend the number of Streptomyces strains known to carry GLPs. Our data also show that most of the $S$. ipomoea strains which we examined carry two or three plasmids and that all of the $S$. lavendulae strains in our study contain GLPs, including the largest GLP found (size, 1,000 $\mathrm{kb}$ ).

Another factor which has major significance for LFRFA taxonomic evaluation is the choice of restriction enzyme(s). The use of rare-site restrictases (28) for generating interpretable patterns is a conditio sine qua non. As the genomes of streptomycetes have high $\mathrm{G}+\mathrm{C}$ contents, the currently available restriction enzymes of choice are DraI (TTT'AAA), AseI (AT'TAAT), and SpeI (A'CTAG). However, other enzymes will undoubtedly be developed. We found that at this time AseI digests are most universally suited (both in number and distribution of fragments) for LFRFA.

The AseI- and DraI-generated LFRFA patterns of the $S$. albus strains showed that this taxon, defined phenotypically by Gordon (10) and Mishra et al. (30), is quite homogeneous. The strains studied have diverse origins (they are often clinical isolates); e.g., they have been obtained from human dental (IMRU 1182), pulmonary (IMRU 1187), and bovine (IMRU 1205) sources. The low-frequency restriction fragment length homogeneity within this group is in good agreement with the morphological and physiological homogeneity of the members of this group (30). Also included in the $S$. albus cluster were two strains of $S$. somaliensis and two strains of $S$. lavendulae, including the type strains of these two species. The members of these three species cannot be 


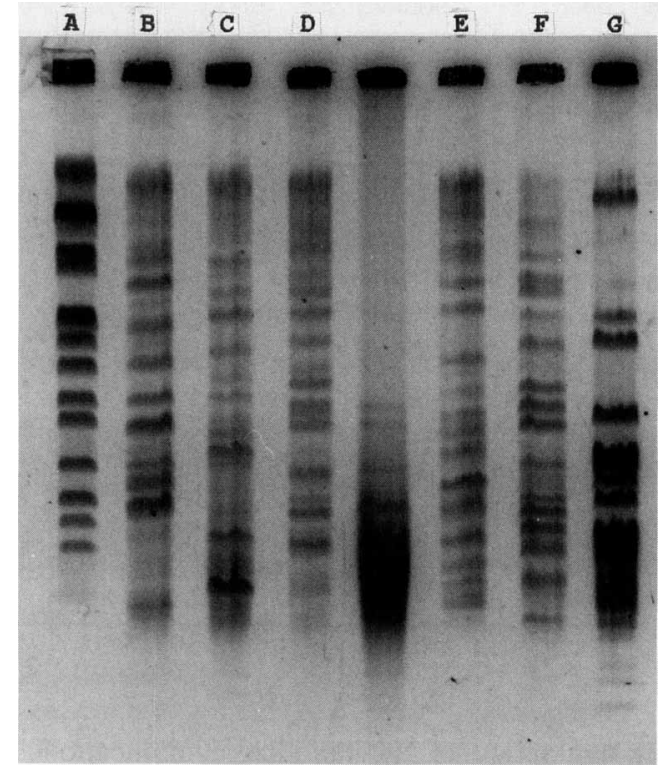

FIG. 8. Pulsed-field gel of $S$. lavendulae strains digested with SpeI. Lane A, Saccharomyces cerevisiae chromosomal standard (see the legend to Fig. 1); lane B, IMRU 467; lane C, IMRU 577; lane D, IMRU 3440-8 ${ }^{\mathrm{T}}$; lane E, IMRU 3445; lane F, IMRU 3455; lane G, IMRU 3555.

differentiated on the basis of their DraI LFRFA patterns since all of them yielded few or no fragments with this enzyme (Fig. 3) (data for $S$. lavendulae and $S$. somaliensis not shown). In contrast, the utilization of a third enzyme, SpeI, permitted the differentiation of $S$. albus and $S$. lavendulae strains. The $S$. albus patterns (Fig. 2) contain many small fragments $(<500 \mathrm{~kb})$ and few large fragments. In contrast, most $S$. lavendulae strains have fragments evenly distributed from 1,200 to $260 \mathrm{~kb}$ (Fig. 8). The exception is $S$. lavendulae IMRU 3555, which has a pattern like the $S$. albus pattern. This information indicates the possible utility of a two- or three-step LFRFA to obtain intracluster separation.

Cluster 2 is made up of eight $S$. fradiae strains, one $S$. somaliensis strain, and one $S$. lavendulae strain. Seven of the $S$. fradiae strains clustered closely at a similarity level 93\%, and three of these strains (IMRU 3535 ${ }^{\mathrm{T}}$, IMRU 3594, and IMRU 3719) produced identical patterns. These three strains, which were independently isolated, produce neomycin, as do IMRU 3572, IMRU 3554, IMRU 1186, and IMRU 1199 . The second cluster containing $S$. fradiae strains (cluster 5) contains only the tylosin producer and two of its mutants and is related to the first cluster at a similarity level of only $70 \%$. This finding may be consistent with the doubts expressed by McGuire et al. (29) in their original discussion about the appropriateness of the assignment of the strains to $S$. fradiae.

Relative low-frequency restriction fragment length homogeneity is also characteristic of clusters 7 and 8 , which contain the 11 test strains belonging to the sweet potatopathogenic species, $S$. ipomoea (6) (Table 4). These strains exhibit high levels of DNA homology (23). Only the type strain of the species (ISP 5383) clustered at some distance from the other $S$. ipomoea strains in the LFRFA; this strain has also been reported to exhibit relatively low levels of DNA relatedness to the other strains and to be not pathogenic for sweet potatoes (20). Thus, we feel that the taxo-
TABLE 4. Comparison of DNA-DNA relatedness and LFRFA similarity values for $S$. ipomoea strains

\begin{tabular}{llccc}
\hline \multicolumn{1}{c}{ Strain } & $\begin{array}{c}\text { Country of } \\
\text { origin }\end{array}$ & $\begin{array}{c}\text { LFRFA } \\
\text { cluster }\end{array}$ & $\begin{array}{c}\text { Similarity } \\
\text { to NRRL } \\
\text { B-16580 as } \\
\text { determined } \\
\text { by LFRFA }\end{array}$ & $\begin{array}{c}\text { \% DNA-DNA } \\
\text { relatedness to } \\
\text { NRRL } \\
\text { B-16580 }\end{array}$ \\
\hline Clark 7849 & United States & 7 & 73 & 91 \\
Clark 7851 & United States & 7 & 78 & 92 \\
Clark 7860 & United States & 7 & 76 & 92 \\
Clark 7862 & United States & 7 & 76 & 93 \\
NRRL B-16445 & United States & 8 & 81 & 95 \\
NRRL B-16480 & Japan & 8 & 100 & 100 \\
NRRL B-16482 & Japan & 8 & 95 & 96 \\
ISP 5358 & United States & NC & 65 & 76 \\
\hline$a$
\end{tabular}

${ }^{a}$ Data from reference 23 .

${ }^{b} \mathrm{NC}$, not clustered.

nomic potential of the LFRFA method demonstrated by the $S$. albus and $S$. fradiae results are reinforced by the results obtained with this species.

The situation with the strains designated $S$. lavendulae, $S$. rimosus, and $S$. somaliensis is more complicated. The $S$. lavendulae and $S$. somaliensis strains digested with AseI showed diverse patterns which taken by themselves could be interpreted as similar, depending on the strain, to the patterns of $S$. albus, $S$. fradiae, or each other. Our findings with $S$. lavendulae lend weight to a recent finding that $S$. lavendulae strains were heterogeneous as measured by DNADNA hybridization (20). The $S$. rimosus strains also exhibited LFRFA heterogeneity. Three presumably independent isolates of $S$. rimosus (IMRU 3558 ${ }^{\mathrm{T}}$, IMRU 3701, and IMRU 3873) were identical, but these organisms exhibited low levels of similarity to the other two strains (58\%).

In addition to the two strains of $S$. somaliensis in cluster 1 discussed above, which were related to each other at a similarity level of $94 \%$, a second cluster (cluster 4) was composed of two other strains of this taxon related at a similarity level of $86 \%$. The three remaining strains studied were found in clusters 2 and 3 and or were unclustered. As discussed above, it is possible that Streptomyces strains may be better differentiated by using a second enzyme in parallel with the first enzyme. It is also possible that, because strains classified as $S$. somaliensis are quite inactive physiologically in the tests of Mishra et al. (30), their apparent phenotypic similarity may not be based on real genomic similarity.

The presumably closely related strains of $S$. coelicolor and $S$. lividans are the strains which have been widely used in genetic studies of streptomycetes. Our finding that these organisms are related at a similarity level of only $73 \%$ confirmed the recent finding of Kieser et al. (16) that the two strains are not closely related, as determined by LFRFA. However, we did not encounter the problem of degradation of $S$. lividans DNA reported by Kieser et al. and Zhou et al. (41), possibly because of our method of growing and treating the cells to be analyzed.

Included in our study for comparative purposes was a group of strains which were defined by numerical taxonomy as the $S$. cyaneus cluster $(38,39)$. The results of DNA relatedness studies performed with these strains (21) suggest that they belong to two major groups and several minor groups. Among the eight strains which we studied which 
TABLE 5. Levels of physiological homogeneity and LFRFA similarity for various Streptomyces species

\begin{tabular}{lcc}
\hline \multirow{2}{*}{ Species } & \multicolumn{2}{c}{$\%$ Similarity as determined by: } \\
\cline { 2 - 3 } & Physiological tests $^{a}$ & LFRFA $^{b}$ \\
\hline S. albus & 85 & 84 \\
S. fradiae & 95 & 81 \\
S. somaliensis & 75 & 75 \\
S. cyaneus & 90 & 58 \\
S. lavendulae & 63 & 67 \\
S. rimosus & 68 & 54 \\
\hline
\end{tabular}

${ }^{a}$ Percentage of tests positive or negative for more than $90 \%$ of the strains. Data from references 10,26 , and 30 .

${ }^{b}$ Level of LFRFA similarity for the strains tested.

represented the two major groups found in the DNA relatedness study, we were not able to discern any clustering whatever. Every strain was unclustered. These strains were not related to any of the other strains belonging to the $S$. cyaneus cluster or to any other member of the taxa which we examined. It is possible that the DNA relatedness levels chosen to demonstrate relatedness (ca. 70\%) were too low. This hypothesis is supported by the fact that the high level of similarity in the LFRFA found for the $S$. ipomoea strains that were analyzed in this study was reflected by the high level of DNA relatedness (ca. 90\%) found in a recent study by the same authors (23) (Table 4).

However, since we found by using the tests of Mishra et al. (30) that the representatives of the $S$. cyaneus group that we studied are $90 \%$ homologous physiologically (Table 5) (26), we concluded that although the results of physiological tests may point to similarities among strains, such tests really measure activities coded for by such a small portion of the whole genome that the apparent phenotypic relationships may not be always borne out when groupings are based on genotypic characterization.

Among more than 100 strains analyzed in our LFRFA study of the genus Frankia (3) we encountered only 2 strains which had identical LFRFA patterns. We thus assumed that because the two strains involved had been isolated in the same laboratory, one was a reisolate of the other. However, the results obtained in this study provide some evidence that apparently independently isolated strains can be identical in their LFRFA patterns. Such strains include $S$. albus ATCC $3004^{\mathrm{T}}$ and ATCC 618 and $S$. fradiae IMRU $3535^{\mathrm{T}}$ and IMRU 3719 (IMRU 3594, which was identical to these strains, was isolated in the same laboratory as IMRU $3535^{\mathrm{T}}$ ). In contrast, the identical strains of $S$. rimosus (IMRU $3558^{\mathrm{T}}$, IMRU 3701, and IMRU 3873), although thought to be independent isolates, all came from the same industrial source. The $S$. ipomoea strains, which clustered at a similarity level of $100 \%$, were all isolated in the same laboratory. Thus, it is still not totally clear whether identical LFRFA patterns imply clonal identity, but the preponderance of evidence from our two studies and the studies of other workers $(2,5)$ seems to suggest that they may.

It is, however, evident that some strains which have been grouped on the basis of phenotype (e.g., S. albus, S. fradiae, and $S$. ipomoea) are also closely related as determined by LFRFA. As shown in Table 5, with one exception (the $S$. cyaneus cluster), the less closely related a species group is phenotypically, the less closely related it is as determined by LFRFA.

We believe that our data emphasize the high potential usefulness of LFRFA for the taxonomy of streptomycetes. At the species level, this method shows clearly that at least some species produce closely related patterns, which may become the basis of a future identification key. Strain differences, as well as similarities, can easily be monitored. It is our belief that, with appropriate additional data obtained by using other suitable restrictases, a good basis for the delineation of Streptomyces species may be established.

\section{ACKNOWLEDGMENTS}

We thank David Labeda and C. A. Clark for providing strains and H. A. Lechevalier for his support of this project.

This research was funded by the International Research and Exchange Board (IREX), a gift from Schering Corp., and the Actinomycete Fund of Rutgers University.

\section{REFERENCES}

1. Allardet-Servent, A., G. Bourg, M. Ramux, M. Pages, M. Bellis, and G. Roizes. 1988. DNA polymorphism in strains of the genus Brucella. J. Bacteriol. 170:4603-4607.

2. Arbeit, R. D., M. Arthur, R. Dunn, C. Kim, R. K. Selander, and R. Goldstein. 1990. Resolution of recent evolutionary divergence among Escherichia coli from related lineages: the application of pulsed field electrophoresis to molecular epidemiology. J. Infect. Dis. 161:230-235.

3. Beyazova, M. L., and M. P. Lechevalier. 1992. Low-frequency restriction fragment analysis of Frankia strains (Actinomycetales). Int. J. Syst. Bacteriol. 42:422-433.

4. Birch, A., A. Hausler, and R. Hutter. 1990. Genome rearrangement and genetic instability in Streptomyces spp. J. Bacteriol. 172:4138-4142.

5. Bohm, J., and H. Karch. 1992. DNA fingerprinting of Escherichia coli O157:H7 strains by pulsed-field gel electrophoresis. J. Clin. Microbiol. 30:2169-2172.

6. Clark, C. A., and B. Watson. 1983. Susceptibility of woody species of Convolvulaceae to root-infecting pathogens of sweet potato. Plant Dis. 69:907-909.

7. Crameri, R. G., G. Hintermann, and R. Hutter. 1983. Deoxyribonucleic acid restriction endonuclease fingerprint characterization of actinomycete strains. Int. J. Syst. Bacteriol. 33:652-655.

8. Fierro, J. F., F. Parra, L. M. Quiros, C. Hardisson, and J. A. Salas. 1987. Heterogeneity of the ribosomal pattern in mycelium of Streptomyces species. FEMS Microbiol. Lett. 41:283-287.

9. Gordon, R. E. 1966. Some criteria for the recognition of Nocardia madurae (Vincent) Blanchard. J. Gen. Microbiol. 45:355-364.

10. Gordon, R. E. 1967. The taxonomy of soil bacteria, p. 293-321. In T. R. G. Gray and B. Parkinson (ed.), The ecology of soil bacteria. Liverpool University Press, Liverpool, England.

11. Gordon, R. E., and A. C. Horan. 1968. A piecemeal description of Streptomyces griseus (Krainsky) Waksman and Henrici. J. Gen. Microbiol. 50:223-233.

12. Grothues, D., and B. Tummier. 1991. New approaches in genome analysis by pulsed-field gel electrophoresis: application to the analysis of Pseudomonas species. Mol. Microbiol. 5:2763-2776.

13. Hershberger, C. L., B. Arnold, J. Larson, P. Skatrud, P. Reynolds, P. Szoke, R. F. Rosteck, Jr., J. Swartling, and D. McGilvray. 1989. Role of giant linear plasmids in the biosynthesis of macrolide and polyketide antibiotics, p. 147-155. In C. L. Hershberger, S. W. Queener, and G. Hegeman (ed.), Genetics and molecular biology of industrial microorganisms. American Society for Microbiology, Washington, D.C.

14. Hightower, R. C., D. W. Metge, and D. V. Santi. 1987. Plasmid migration using orthogonal-field-alternation gel electrophoresis. Nucleic Acids Res. 15:8387-8398.

15. Kalkus, J., M. Reh, and H. G. Schlegel. 1990. Hydrogen autotrophy of Nocardia opaca strains is encoded by linear megaplasmids. J. Gen. Microbiol. 136:1145-1151.

16. Kieser, H. M., T. Kieser, and D. A. Hopwood. 1992. A combined genetic and physical map of the Streptomyces coelicolor A3/2 
chromosome. J. Bacteriol. 174:5496-5507.

17. Kinashi, H., and M. Shimaji. 1987. Detection of giant linear plasmids in antibiotic producing strains of Streptomyces by the OFAGE technique. J. Antibiot. 40:913-916.

18. Kirby, R., and E. P. Rybicki. 1986. Enzyme-linked immunosorbent assay (ELISA) as a means of taxonomic analysis of Streptomyces and related organisms. J. Gen. Microbiol. 132: 1891-1894.

19. Labeda, D. P. (Northern Regional Research Center, Peoria, Ill.). 1991. Personal communication.

20. Labeda, D. P. 1992. DNA-DNA hybridization in the systematics of Streptomyces. Gene 115:249-253.

21. Labeda, D. P., and A. J. Lyons. 1991. Deoxyribonucleic acid relatedness among species of the Streptomyces cyaneus cluster. Syst. Appl. Microbiol. 14:158-164.

22. Labeda, D. P., and A. J. Lyons. 1991. The Streptomyces violaceusniger cluster is heterogeneous in DNA relatedness among strains: emendation of the descriptions of $S$. violaceusniger and Streptomyces hygroscopicus. Int. J. Syst. Bacteriol. 41:398-401.

23. Labeda, D. P., and A. J. Lyons. 1992. DNA relatedness among strains of the sweet potato pathogen Streptomyces ipomoea (Person and Martin 1940) Waksman and Henrici 1948. Appl. Environ. Microbiol. 58:532-535.

24. Leblond, P., F. X. Francou, J.-M. Simonet, and B. Decaris. 1990. Pulsed-field gel electrophoresis analysis of the genome of Streptomyces ambofaciens strains. FEMS Microbiol. Lett. 72:79-88.

25. Lechevalier, H., and M. P. Lechevalier. 1981. Introduction to the order Actinomycetales, p. 1915-1922. In M. P. Starr, H. Stolp, H. G. Trüper, A. Balows, and H. G. Schlegel (ed.), The prokaryotes, vol. 2. Springer-Verlag, Berlin.

26. Lechevalier, M. P. 1991. Unpublished data.

27. Maniatis, T., E. F. Fritsch, and J. Sambrook. 1982. Molecular cloning: a laboratory manual, p. 438. Cold Spring Harbor Laboratory, Cold Spring Harbor, N.Y.

28. McClelland, M., R. Jones, Y. Patel, and M. Nelson. 1987. Restriction endonucleases for pulsed-field mapping of bacterial genomes. Nucleic Acids Res. 15:5985-6005.

29. McGuire, J. M., W. S. Boniece, C. E. Higgens, M. M. Huehn, W. M. Stark, J. Westhead, and R. N. Wolfe. 1961. Tylosin, a new antibiotic. I. Microbiological studies. Antibiot. Chemother.
(Washington, D.C.) 11:320-327.

30. Mishra, S. K., R. E. Gordon, and D. A. Barnett. 1980. Identification of nocardiae and streptomycetes of medical importance. J. Clin. Microbiol. 11:728-736.

31. Ochi, K. 1992. Polyacrylamide gel electrophoresis analysis of ribosomeal protein: a new approach for actinomycete taxonomy. Gene 115:261-265.

32. Pridham, T. G., and H. D. Tresner. 1974. Family VII. Streptomycetaceae Waksman and Henrici, p. 747-845. In R. E. Buchanan and N. E. Gibbons (ed.), Bergey's manual of determinative bacteriology, 8th ed. Williams \& Wilkins, Baltimore.

33. Shirling, E. B., and D. Gottlieb. 1972. Cooperative description of type strains of Streptomyces. Int. J. Syst. Bacteriol. 22:265394.

34. Smith, C. L. (Columbia University). 1986. Personal communication.

35. Smith, C. L., and C. R. Cantor. 1987. Purification, specific fragmentation and separation of large DNA molecules. Methods Enzymol. 55:449-467.

36. Sneath, P. H. A., and R. R. Sokal. 1973. Numerical taxonomy. W. H. Freeman and Co., San Francisco.

37. Waksman, S. A. 1967. The actinomycetes, p. 249. Ronald Press, New York.

38. Williams, S. T., M. Goodfellow, and G. Alderson. 1989. Genus Streptomyces Waksman and Henrici 1943, 339AL, p. 2452-2492. In S. T. Williams, M. E. Sharpe, and J. B. Holt (ed.), Bergey's manual of systematic bacteriology, vol. 4. Williams \& Wilkins, Baltimore.

39. Williams, S. T., M. Goodfellow, G. Alderson, E. M. H. Wellington, P. H. A. Sneath, and M. J. Sackin. 1983. Numerical classification of Streptomyces and related genera. J. Gen. Microbiol. 129:1743-1813.

40. Witt, D., and E. Stackebrandt. 1990. Unification of the genera Streptoverticillium and Streptomyces and amendation of Streptomyces Waksman and Henrici 1943, 339 ${ }^{\mathrm{AL}}$. Syst. Appl. Microbiol. 13:361-371.

41. Zhou, X., X. Deng, J. L. Firmin, D. A. Hopwood, and T. Kieser. 1988. Site-specific degradation of Streptomyces lividans DNA during electrophoresis in buffers contaminated with ferrous iron. Nucleic Acids Res. 16:4341-4352. 